\title{
PERANAN TUAN GURU HAJI MUHAMMAD KASYFUL ANWAR DAN TUAN HAJI SETTA DALAM MENDIRIKAN PESANTREN DARUSSALAM MARTAPURA, KABUPATEN BANJAR, KALIMANTAN SELATAN, 1924
}

\author{
Yusliani Noor* \& Rabini Sayyidati** \\ *Program Studi Pendidikan Sejarah, Universitas Lambung Mangkurat \\ Banjarmasin \\ **Program Studi Teknik Informatika, Politeknik Negeri Tanah Laut \\ Tanah Laut
}

rabini.sayyidati@gmail.com

\begin{abstract}
Abstrak
Dalam kehidupan sosial-ekonomi masyarakat Banjar di Kalimantan Selatan mengenal pula kelompok pedagang dan pengusaha. Pedagang dan pengusaha yang sukses, dikenal dengan istilah; saudagar dan juragan. Sebutan kehormatan untuk meraka adalah Tunji, singkatan dari Tuan Haji. Sejak tahun 1892 Pemerintah Kolonial Belanda telah mendirikan sekolah Kelas Dua untuk anak-anak rakyat biasa dan juga sekolah untuk anak-anak pegawai Pemerintah Kolonial. Motivasi memajukan pendidikan Islam di Martapura Kalimantan Selatan sejak 1900 semakin besar. Mengingat daerah lainnya telah mendirikan sekolah Islam. Lembaga pendidikan Islam tersebut, sebagai upaya mengimbangi intensifnya Pemerintah Kolonial Belanda dalam mendirikan sekolah-sekolah sekuler di Banjarmasin. Dalam rangka menahan arus pengaruh pendidikan barat yang dikelola Pemerintah Kolonial Belanda, Tuan Guru Muhammad Kasyful Anwar bekerjasama dengan Tuan Haji Setta, seorang saudagar Banjar mendirikan Pesantren Darussalam di Martapura, Kabupaten Banjar Kalimantan Selatan. Setidaknya, Pesantren Darussalam Martapura, Kalimantan Selatan menjadi bagian penting dalam membentuk karakter masyarakat Islam, yang memiliki ciri Ahlussunnah wal-jamaah, dengan tradisi ke NU-an.
\end{abstract}

Kata Kunci: Tuan Guru, Tuan Haji, Pesantren.

\begin{abstract}
The term merchant and entrepreneur were also known in the socio-economic days of Banjar community in South Kalimantan. Successful merchant and entrepreneur were known by the term of saudagar and juragan. The honorable name for them was Tunji, an abreviation from Tuan Haji. Ever since the 1892, Dutch colonial government had built a second grade school for the children of common people and a school for the children of the colonial government employees. The motivation to empower Islamic education in Martapura, South Kalimantan, ever since 1900 has grown significantly, especially because other areas have established Islamic schools. Such Islamic educational institutions were an effort to counterbalance the frequent establishment of secular schools in Banjarmasin by the Dutch Colonial Government. In order to withstand the influences of western education managed by the Dutch Colonial Government, Tuan Guru Muhammad Kasyful Anwar worked with Tuan Haji Setta, a Banjar saudagar, to establish a Pesantren Darussalam in Martapura,
\end{abstract}


Banjar regency, South Kalimantan. Considerably, Pesantren Darussalam Martapura, South Kalimantan, had become a significant part in shaping the character of Islamic society, with the characteristics of Ahlussunnah wal-jamaah mixed with NU tradition

Keywords: Tuan Guru, Tuan Haji, Islamic Boarding School

\section{PENDAHULUAN}

Kota Martapura, Kabupaten Banjar Kalimantan Selatan, terkenal dengan sebutan Kota Santri, dan disebut 'Serambi Mekkah'. Sebutan itu disebabkan banyaknya Ulama, yang disebut dengan istilah Tuan Guru. Selain itu, kota Martapura memiliki Pondok Pesantren Darussalam, yang berdiri dalam tahun 1924,1 dan dikenal sebagai Pesantren Nahdlatul Ulama. Pesantren ini dianggap sebagai penerus Pesantren Dalam Pagar yang telah dibina oleh Syekh Muhammad Arsyad Al-Banjary.

Dalam kehidupan sosial-ekonomi masyarakat Banjar di Kalimantan Selatan mengenal pula kelompok pedagang dan pengusaha. Pedagang dan pengusaha yang sukses, dikenal dengan istilah; saudagar dan juragan. Sebutan kehormatan untuk meraka adalah Tunji, singkatan dari Tuan Haji. Tuan Haji memiliki posisi yang sangat penting dalam masyarakat Banjar, sejak abad ke-19 sampai abad ke-20. Seorang Tuan Haji dikenal sebagai pedagang dan pengusaha yang tidak terpisahkan dengan dakwah Islam. Mereka senantiasa bersinergi dengan Tuan Guru. Khususnya dalam memajukan masyarakat Islam. Mereka sangat aktif terlibat dalam membangun mesjid, surau (langgar), tempat pengajian, madrasah dan pesantren.

Kekuatan sinergis antara Tuan Guru dan Tuan Haji selalu eksis di Kesultanan Banjarmasin, meskipun situasi politik dan pemerintahan mengalami perubahan yang mendasar. Termasuk ketika Kesultanan Banjarmasin telah dihapuskan Belanda, sejak 11 Juni 1860. 2 Pemerintah Kolonial berhasil menguasai Kesultanan Banjarmasin dan mengatur sistem birokrasi pemerintahannya. Termasuk membuka sekolah-sekolah umum (sekuler) bagi masyarakat muslim di Martapura Kalimantan Selatan.

Sejak tahun 1892 Pemerintah Kolonial Belanda telah mendirikan sekolah Kelas Dua untuk anak-anak rakyat biasa dan juga sekolah untuk anak-anak pegawai Pemerintah Kolonial. Di Kalimantan Selatan Pemerintah Kolonial Belanda mendirikan 196 buah Sekolah Rendah, Hollands Inleandse School 3 buah, Hollands Chinese School 1buah, Schakel School 1 buah, Europese Lagers

${ }^{1}$ Sjarifuddin, Sikap Pergerakan Rakyat Menghadapi Pendudukan Belanda di Kalimantan Selatan Periode 1945 sampai Dengan 17 Agustus 1950, (Banjarmasin: Fakultas Keguruan Universitas Lambung Mangkurat, 1974), hlm. 288

2 Helius Sjamsuddin, Pagustian dan Tumenggung, Akar Sosial, Politik, Etnis, dan Dinasti Perlawanan di Kalimantan Selatan dan Kalimantan Tengah 1859-1906, (Jakarta: Balai Pustaka, 2001), hlm. 184 
School 1 buah, Cursus Volke Onderwijs 8 buah, Klein Handel School 3 buah, Middelbaar Uitgebreid Lager Onderwijs 1 buah, dan Inheemse Mulo 1buah.3

Motivasi memajukan pendidikan Islam di Martapura Kalimantan Selatan sejak 1900 semakin besar. Mengingat daerah lainnya telah mendirikan sekolah Islam. Misalnya tahun 1915 di Banjarmasin berdiri Arabische School, menyusul Almadrasatul Arabiyah Alwathaniyah. Kemudian di Amuntai tahun 1919 berdiri Perguruan Islam Rasyidiyah, dan lain-lain. Lembaga pendidikan Islam tersebut, sebagai upaya mengimbangi intensifnya Pemerintah Kolonial Belanda dalam mendirikan sekolah-sekolah sekuler di Banjarmasin. Pada wilayah Martapura Kabupaten Banjar sendiri Pemerintah Kolonial Belanda sampai tahun 1934 memiliki 25 sekolah rakyat dan 2 sekolah lanjutan (Vervolgschool).4

Arus sekulerisasi pendidikan barat abad ke-19 dalam masyarakat muslim di Martapura khususnya, dan Kalimantan Selatan umumnya, tidak bisa terhindarkan. Dalam rangka menahan arus pengaruh pendidikan barat yang dikelola Pemerintah Kolonial Belanda, Tuan Guru Muhammad Kasyful Anwar bekerjasama dengan Tuan Haji Setta, seorang saudagar Banjar mendirikan Pesantren Darussalam di Martapura, Kabupaten Banjar Kalimantan Selatan. Setidaknya, Pesantren Darussalam Martapura, Kalimantan Selatan menjadi bagian penting dalam membentuk karakter masyarakat Islam, yang memiliki ciri Ahlussunnah wal-jamaah, dengan tradisi ke NU-an. Pelopor pendirian pesantren tersebut, tidak bisa dipisahkan dari peran Tuan Guru dan Tuan Haji di Martapura, Kalimantan Selatan

\section{METODE PENELITIAN}

Penelitian ini menggunakan metode sejarah. Dalam metode sejarah, digunakan empat tahapan penelitian, sebagai berikut:

1. Tahap Heuristik, yakni tahapan menggali sumber-sumber sejarah, antara lain:

a. Sumber tertulis. Pada tahapan ini, penulis akan mencoba menggali arsip-arsip yang berkaitan judul penelitian.

b. Sumber lisan. Pada tahapan awal ini, penulis melakukan wawancara pada berbagai tokoh di Martapura yang mengetahui kisah sejarah berdirinya Pesantren Darussalam.

2. Tahap Kritik, dalam tahap ini, penulis melakukan kritik interen dan eksteren. Kritik interen yakni berupaya melakukan kritik terhadap berbagai sumber yang diperoleh. Kritik interen pada arsip-arsip berkaitan dengan substansi materi kajian yang diteliti, khususnya yang berkaitan langsung

\footnotetext{
3 Sjarifuddin, Op.cit, hlm. 282

4 ANRI, Memorie Van Overgave Voor De Onderafdeeling Martapoera Door Controleur J. Wentholt, 10 Nov. 1938. Reel no. 30, MvO serie 1e, ANRI hlm. 33-35.
} 
dengan rumusan masalah yang diteliti, Pada sumber lisan kritik eksteren digunakan untuk menguji keabsahan kualifikasi informan yang selalu hidup dan tinggal di Martapura dan mengetahui mengenai pendirian Pesantren Darussalam. Tahapan Kritik merupakan tahapan verifikasi (pemilahan ilmiah) data yang diperoleh, sehingga kemudian data yang benar dan sahih atau valid dapat disebut sebagai fakta sejarah.

3. Interpretasi, tahapan interpretasi merupakan tahapan penafsiran yang dikerjakan setelah tahap kritik. Interpretasi fakta sejarah dalam penelitian ini, berhubungan dengan kajian lingkungan sosial. Kajian lingkungan sosial tidak terlepas dari geografi sosial, dalam konteks kependudukan, pemukiman, dan budaya etnisitas. Sementara itu, fakta dan data yang didapat memerlukan panafsiran yang disesuaikan dengan upaya memahami konteks peristiwa yang terjadi.

4. Historiografi, Tahapan historiografi merupakan tahapan penulisan kisah sejarah, setelah melalui tahapan interpretasi. Pemaparan secara naratif tentang Peranan Tuan Guru Haji Muhammad Kasyful Anwar dan Tuan Haji Setta dalam Mendirikan Pesantren Darussalam Martapura Kabupaten Banjar Kalimantan Selatan 1924 , akan tersaji dalam tahapan historiografi.

\section{HASIL DAN PEMBAHASAN}

\section{A. Eksistensi Tuan Guru dan Tuan Haji}

Istilah Tuan Guru sudah lama dikenal masyarakat Banjar. Sejak Syekh Muhammad Arsyad Al-Banjary pulang dari Negeri Mekkah, dan singgah di Batavia, kemudian mampu menghadapi para ilmuwan Belanda, khususnya ketepatan mengukur kedalaman laut Batavia. Gubernur Hindia Belanda van de Parra memberinya gelar Tuan Haji Besar,5 dan Tuan Surgi.6 Ketika sampai di Martapura, pertengahan abad ke-18, ia membuka Pesantren Dalam Pagar dan menjadi guru. Syekh Muhammad Arsyad Al-Banjary kemudian dikenal pula sebagai Tuan Guru. Para zuriatnya, yang meneruskan pengabdian menjadi guru agama Islam dikenal dengan sebutan Tuan Guru.

Syekh Muhammad Arsyad Al-Banjary membentuk sebuah lembaga yang diberi nama "Dalam Pagar". Pimpinannya adalah Syekh Muhammad Arsyad Al-Banjary sendiri, dibantu oleh Syekh Abdul Wahab Bugis (Sadenreng Bungo Wardiyah), sahabat sekaligus menantunya. Lembaga dibentuk atas restu Sultan Tahmidullah II, yang memberinya sebidang tanah yang sangat luas, untuk

${ }^{5}$ Abu Daudi, Maulana Syekh Muhammad Arsyad Al-Banjari (Tuan Haji Besar), (Martapura-Kalsel: Yayasan Pendidikan Islam Dalam Pagar), 2003), hlm. 59-60.

${ }^{6}$ Sebutan Tuan Surgi kepada Syekh Muhammad Arsyad Al-Banjary muncul sejak abad ke-19. Namun, sebutan ini lebih melekat kepada zuriatnya, yakni Tuan Surgi Syekh Jamaluddin Surgi Mufti. 
mengembangkan pendidikan. Boleh dikatakan, Dalam Pagar adalah pesantren model khas Timur Tengah dengan sistem Sorogan.

Pembelajaran tahap pemula, baik bagi anak-anak maupun orang dewasa adalah belajar mengaji atau membaca Al-Qur'an, dengan maksud mengenal langsung huruf-huruf Hijaiyyah. Guru biasanya duduk dimuka murid, sedangkan murid duduk menghadap guru, ditengah antara guru dan murid ada sebuah rehal (meja kecil berbentuk huruf X), sehingga murid belajar dengan huruf yang normal, kemudian guru melihat huruf-huruf Al-Qur'an secara terbalik.

Syekh Muhammad Arsyad Al-Banjary menerapkan pengajian dengan sistem Sorogan, yakni pengajian dengan pola seperti huruf ' $U$ ', sedangakan Guru duduk pada posisi bagian kosong tengah, sambil menghadap murid. Guru membacakan kitab, dan murid mendengarkan dengan seksama. Syekh Muhammad Arsyad Al- Banjary dalam waktu yang singkat telah berhasil mendidik anak dan cucunya. Syarifah binti Syekh Muhammad Arsyad AlBanjary ikut belajar mengaji dan menuntut ilmu, begitu pula Muhammad As'ad binti Syarifah dan Fathimah binti Syarifah (dengan Abdul Wahab Bugis).7

Fathimah adalah anak dari Syarifah dengan Syekh Abdul Wahab Bugis. Fathimah adalah cucu Syekh Muhammad Arsyad Al-Banjary yang belajar langsung dengan kakeknya itu. Ia menguasai ilmu 'Arabiyah, ilmu tafsir, ushuluddin, dan fiqih, sehingga merupakan perempuan pertama yang menjadi ustazah di Kesultanan Banjarmasin, serta berhasil membuat sebuah kitab 'Parukunan Besar'.8 Namun, karena tabiatnya yang rendah hati serta tidak lazimnya seorang perempuan menampilkan diri, khususnya dalam akhir abad ke-18, maka Fathimah tidak mau mencantumkan namanya sendiri, untuk itu ia mencantumkan nama pamannya Mufti Jamaluddin bin Syekh Muhammad Arsyad Al-Banjary.9

Fathimah kemudian menjadi ustazah bagi kaum perempuan di Kesultanan Banjarmasin, khususnya bagi perempuan yang ingin mengaji Alqur'an, ilmu fiqih dan ushuluddin. Sejak Fathimah muncul sebagai perempuan intelektual, maka kaum perempuan Banjarmasin mulai mendapat tempat dalam menimba ilmu agama, khususnya yang berkenaan dengan hukum haid, nifas, wiladah, mandi junub dan lain-lain, yang sebelumnya diajarkan sematamata bagi kalangan laki-laki.10

7 Ibid, hlm. 73, lihat juga M. Ramli Nawawi et.al, Sejarah Pendidikan di Kalimantan Selatan (Banjarmasin: Departemen Pendidikan dan Kebudayaan Kalimantan Selatan, 1980/1981), hlm. 15.

${ }^{8}$ Abu Daudi, Ibid, hlm. 74

${ }^{9}$ Ibid. Dalam menyebut kitab 'Parukunan Besar' ini, masyarakat Martapura ada yang menyebut 'Parukunan Fathimah', ada pula yang menyebutnya 'Parukunan Jamaluddin'.

10 Sebelum Fathimah belum ditemukan bukti-bukti sejarah yang menjelaskan adanya perempuan Banjar yang menjadi intelektual Muslimah atau Ustazah. Fathimah telah mengajarkan ilmu agama kepada kaum perempuan di Kesultanan Banjarmasin. Bandingkan dengan R.A, Kartini yang wafat dalam tahun 1904, masih merindukan pengajaran bagi kaum perempuan Jawa di Pulau Jawa, lihat A. K. Pringgodigdo, 1978, Sejarah Pergerakan Rakyat Indonesia, Jakarta: PT. Dian Rakyat, 
Tradisi pengajian Syekh Muhammad Arsyad Al-Banjary juga mengenal pengajian 'Ma-Arba', yakni pengajian yang berlangsung setiap hari Arba atau Rabu.11 Dalam pengajian ini, guru membacakan kitab, sedangkan murid hanya mendengarkan saja segala ilmu yang diuraikan guru.

Dengan sistem pengajian 'Dalam Pagar' Syekh Muhammad Arsyad AlBanjary berhasil membangun sistem jaringan sosial yang menempatkan Bubuhan, yakni kalangan zuriyatnya sebagai penyebar Islam yang bersifat struktural, sehingga perluasan Islam meluas ke seluruh Banjarmasin (Kalimantan Selatan, Tengah, Barat, dan sebagian Timur). Murid-murid dan kerabatnya kemudian membentuk jaringan sosial lanjutan, untuk dakwah Islam di kawasan Banjarmasin.

Untuk menopang pembelajaran pesantren 'Dalam Pagar', Syekh Muhammad Arsyad Al-Banjary membuat karya tulis berbentuk kitab, yakni kitab; Tuhfaturragibien, Qaulul Mukhtasyar, Kanzul Ma'rifah, Kitab Nikah, AlFaraid, Arkanul Ta'limi Sibyan, Ushuluddin, Bulughul Maram, Fil Bayani Qada Wal Qadar Wabaa, Tuhfatul Ahbaab, Fathul Jawad, dan Sabilal Muhtadien.12

Syekh Muhammad Arsyad Al-Banjary juga membuat salinan Al-qur'an dengan tulisan tangannya sendiri. Sebagian kitab-kitab tersebut ditulis dalam bahasa Banjar, sehingga mudah dipelajari secara luas dikalangan masyarakat Kesultanan Banjarmasin. Zuriyat Syekh Muhammad Arsyad Al-Banjary dan murid-muridnya secara berantai membentuk jaringan sosial, mengajarkan kitab-kitab tersebut, yang sebarannya bukan saja wilayah Banjarmasin, bahkan juga kawasan Asia Tenggara.

Sementara itu, eksistensi Tuan Haji di Kesultanan Banjarmasin sudah muncul pada abad ke-17.13 Mereka bermitra dengan Kesultanan Banjar dalam melakukan perdagangan lada. Eksistensi mereka dapat ditelusuri dengan munculnya kelas saudagar di Kesultanan Banjarmasin. meskipun sebagian mereka masih keturunan bangsawan Banjar. Sesudah Perang Banjar (1859-1906) kehidupan sosial ekonomi Banjar di Martapura dikontrol sepenuhnya oleh pemerintah Belanda. Berbagai hasil sumber daya alam Martapura selalu mendapatkan cukai dan pajak dari pemerintah yang berkuasa saat itu. Kekuasaan pemerintah Belanda di Afdeeling Martapura sejak 1901 dipimpin oleh Asistent Resident E. A. Klerks. Ia berfungsi sebagai Vendumesteer (Kepala

hlm. 20, sementara Fathimah binti Syarifah bin Syekh Muhammad Arsyad Al-Banjary dalam abad ke-18 (1790-an) telah mengarang sebuah Kitab Parukunan, untuk kaum perempuan dan laki-laki. Artinya, perempuan Banjarmasin lebih maju dari perempuan ningrat Jawa, seperti hasrat dari Kartini, dalam buku "Habis Gelap Terbitlah Terang".

${ }^{11}$ M. Ramli Nawawi, et.al, Op.cit. hlm. 15-16

12 Abdurrahman, Menelusuri Karya Tulis Ulama Banjar (Bagian IV) Menelusuri Karya Syekh Muhammad Arsyad Al-Banjari, Surat Kabar Dinamika Berita, 21 November 1991.

13 Tuan Haji Syahabuddin Negara, telah dikenal sebagai ayah dari Datu Haji Muhammad Taher Negara. Lihat Yustan Aziddin et.al, Cerita Rakyat Daerah Kalimantan Selatan (Jakarta: departemen Pendidikan dan Kebudayaan Proyek Inventarisasi dan Dokumentasi Kebudayaan Daerah, 1980/1981), hlm 59-70. 
Lelang). Kepala Distriknya adalah Kiai Jaya Kesuma Negara. Kepala Distrik Riam Kiwa adalah Kiai Abdul Mutalib.14 Seorang regent yang bernama Pangeran Jaya Pamenang.15

Orang Banjar sangat gigih dalam melawan Belanda, yang ditandai dengan Perang Banjar. Perang ini berlangsung dalam rentang waktu yang cukup panjang (1859-1906). Menurut Tamny Ruslan dalam risetnya tentang Gerakan Nativisme di Muning, sebenarnya Perang Banjar berawal dari gerakan ketidakpuasan rakyat kepada ikut campur tangannya Belanda dalam urusan suksesi istana Banjar, dan keresahan masyarakat atas pajak yang sangat menjerat rakyat, khususnya para petani.16 Imbas gerakan ini menghasilkan perlawanan rakyat yang sangat dahsyat. Ita Syamtasiah Ahyat, menyebutnya sebuah perlawanan yang kian meningkat.17 Pajak yang diterapkan pemerintah kolonial memang memberatkan petani, namun seiring dengan waktu, apalagi sesudah tahun 1910, Martapura relatif stabil.18 Gerakan perlawanan rakyat Banjar telah berhasil dilumpuhkan Belanda melalui taktik adu domba dan belah bambu.

Kehidupan masyarakat mulai dikelola Pemerintah Kolonial Belanda di Martapura Kalimantan Selatan dalam berbagai aspek. Khususnya aspek ekonomi dan politik. Kehidupan terus bergerak. Oleh sebab itu, hukum ekonomi akan berpihak kepada mereka yang memiliki kesempatan dalam membangun bisnisnya. Khususnya kalangan pribumi. Dalam konteks ini, Linblad menyatakan sebagai berikut:

“Terdapat akses yang lebih besar untuk pribumi yang juga menstimulasi perdagangan pantai dan sungai yang memperdagangkan semua barang konsumen, termasuk bahan makanan non-beras. Banjarmasin berfungsi sebagai sebuah pusat pasar bahan pokok, bukan hanya dilakukan antara pedagang Cina saja, namun juga oleh komunitas Eropa yang menginginkan barang konsumen itu. Pada tahun 1913, tidak kurang dari 1,3 juta kg tepung."19

Fenomena yang digambarkan Linblad dalam perspektif ekonomi, menggambarkan peningkatan nilai impor yang masuk ke Banjarmasin. Nilai

14 Alex A. Koroh, Lintasan Sejarah Pemerintahan Daerah di Kalimantan Selatan 19011957.(Banjarbaru: Scripta Cendekia, 2009), hlm. 8.

15 M. Idwar Saleh, dkk. Sejarah Daerah Kalimantan Selatan (Banjarmasin: Proyek Penelitian Pencatatan Daerah Depdikbud, 1978), hlm. 65.

16 Tamny Ruslan, Gerakan Muning: Sebuah Gerakan Sosial di Dalam Perang Banjar. Tesis. (Yogyakarta: Fakultas sastra dan Kebudayaan Universitas Gadjah Mada dalam Ilmu Sejarah, 1981).

17 Ita Syamtasiah Ahyat. Kesultanan Banjarmasin Pada Abad Ke-19 Ekspansi Pemerintah HindiaBelanda di Kalimantan. (Tangerang: SAM), 2012, hlm. 221.

18 Pemerintah Kolonial memulai gerakan pembangunan di Kalimantan Selatan, khususnya di Martapura Kalimantan Selatan. Pembangunan untuk kepentingan penduduk, khususnya bidang irigasi untuk pertanian sejak 1903. Lihat Memorie Van Overgave J.F.A. de Rooy, 1905 Reel nomor 3, MvO DL, ANRI.hlm. 8-9.

19 J. Thomas Linblad. Antara Dayak dan Belanda, Sejarah Ekonomi Kalimantan Timur dan Kalimantan Selatan 1880-1942. ( Malang-Jakarta: Lilin-KITLV), 2012, hlm. 19-20 
impor yang dipaparkan Linblad menjelaskan kebutuhan Banjarmasin yang memang dikuasai sepenuhnya oleh pemerintah kolonial Belanda. Fakta ini, menguraikan pula betapa kondusifnya Banjarmasin dalam tahun 1913. Bahkan Linblad menyebutkan pada pergantian abad dari tahun 1899 ke tahun 1900, Banjarmasin masih menawarkan ketenangan di luar Hindia Belanda.20 Sangat mungkin maksud tersirat dari penjelasan Linblad ini berkaitan dengan ketenangan keamanan dan laju ekspor-impor.

Kota Martapura sebagai kota bernuansa Islam digambarkan H.M. Holtrust dalam memorinya sebagai berikut:

"Mesjid yang indah di ibukota Martapura. Padatnya kunjungan sholat Jumat di kota Martapura dan mesjid-mesjid lain. Banyaknya langgar di berbagai perkampungan. Jumlah haji yang bisa disebutkan pada tahun 1924, 1925, 1926 dan 1927 : 237, 12, 68 dan 128 orang. Besarnya jumlah pesantren Melayu yaitu 385 buah. Pentingnya sosok sejarah Tuan Guru Haji Mohammad Arsyad Al-Banjary alias Haji Besar, ulama terkenal yang pada tahun-tahun sebelumnya oleh raja (Sultan Banjar) dikirim ke Arab untuk belajar teologi dan memberikan pengaruh pada kehidupan agama di Martapura. Makamnya di Kalampayan menjadi sangat keramat di seluruh Borneo dan Kampung Dalam Pagar tempat banyak keturunannya tinggal sejak dahulu menampung banyak orang alim".21

Artinya, masyarakat Martapura Kabupaten Banjar Kalimantan Selatan adalah masyarakat muslim, yang sangat ta'at dalam melaksanakan ibadah. Khususnya ibadah sholat Jum'at. Hal ini dibuktikan lagi dengan lumayan banyaknya orang Banjar di Martapura Kalimantan Selatan yang berangkat haji ke Mekkah.

Banyaknya jumlah penduduk yang naik haji tahun 1924 menunjukkan membaiknya ekonomi perdagangan di Martapura. Begitu pula dalamn tahun 1927. Sementara tahun 1925 dan 1926, sedikit yang naik haji disebabkan beberapa komoditas perdagangan mengalami kemerosotan harga. Misalnya berkurangnya nilai harga intan dan batu bara.

Terbukanya ruang bagi komunitas pribumi, tidak bisa dilepaskan dari afiliasi jaringan pengusaha pribumi dengan pemerintah kolonial saat itu. Pengusaha pribumi dalam konteks tahun 1900 di Martapura Kalimantan Selatan tidak bisa dilepaskan dari menaiknya status golongan saudagar Banjar sejak abad ke-18 sampai abad ke-19. Golongan saudagar Banjar adalah para Haji yang memiliki status sosial yang kuat di masyarakat Banjar.22Saudagar Banjar yang bergelar Tunji atau Tuan Haji merupakan predikat wirausahawan

\footnotetext{
${ }^{20}$ Ibid, hal. 14

${ }^{21}$ ANRI, Memorie van Overgave Onderafdeeling Martapoera Door H.M. Holtrust Reel no. 30, MvO serie 1e, ANRI 1928, hlm 15-16.

22 Yusliani Noor. Islamisasi Banjarmasin (Abad Ke-15 Sampai Ke-19). (Yogyakarta; Penerbit Ombak, 2016), hlm 269
} 
muslim Banjar. Mereka diakui oleh masyarakatnya, khususnya untuk kawasan Martapura Kalimantan Selatan.

\section{B. Tuan Guru Muhammad Kasyful Anwar dan Tuan Haji Setta: Bekerjasama Mendirikan Pesantren Darussalam Martapura}

Tuan Guru Muhammad Kasyful Anwar dilahirkan di Kampung Melayu, pada malam Selasa 4 Rajab 1304 Hijriah. Ibunya bernama Hajjah Siti Mariyyam binti Haji Abdurrahim. Ayahnya bernama Haji Ismail bin Haji Muhammad Arsyad. Dalam tahun 1313 Hijiriah ia berangkat sekeluarga ke Mekkah, kemudian bermukim disana selama 17 tahun lamanya, sambil belajar ilmu agama kepada para Syekh.23 Diantaranya ia berguru kepada Syekh Umar Hamdan al-Mahrus yang bergelar Muhaddist al-Haramain. Syeikh Sayyid Ahmad bin Hasan Al-Atthas, penulis kitab Tazkirannas. Syekh Umar Ba Junaid, seorang Mufti Syafiyyah, Syekh Muhammad Ahyad Al-Bogori, dan lain-lain.24

Pada tahun $1330 \mathrm{H}$, ia kembali ke Indonesia dan kembali ke kampung halamannya di Kampung Melayu. Dalam tahun 1919 M, kembali ia berangkat ke tanah suci Makkah. Sambil memperdalam beberapa bidang ilmu agama, ia dipercaya mengajar di Masjidil Haram, Makkah. Setelah tiga tahun di Mekkah, ia kembali ke Kampung Melayu dalam tahun 1922.25

Sambil mengajar murid-muridnya, Tuan Guru Haji Muhammad Kasyful Anwar bekerjasama dengan Tuan Haji Setta, seorang pedagang dan pengusaha di Martapura. Mereka bekerjasama dalam jual beli intan berlian dan usaha karet. Tuan Guru Muhammad Kasyful Anwar menjadi guru sekaligus teman dari Tuan Haji Setta. Tuan Haji Setta sendiri seorang yang memiliki pengetahuan yang luas dalam agama Islam. Sejak 1922 Tuan Guru Haji Muhammad Kasyful Anwar memimpin Darussalam Martapura, kemudian melakukan pembaharuan sejak 1924. Bersama Tuan Haji Setta ia mendirikan pesantren Darussalam dengan sistem kelas. Ia mengajar dengan pola ceramah dan tanya jawab. Sementara dalam ilmu bahasa menggunakan metode assyahid, yakni sejenis ilmu uraian bahasa. 26

Untuk kepentingan pembelajaran di Peantren Darussalam, Tuan Guru Muhammad Kasyful Anwar menulis buku, diantaranya; Risalah Tauhid, Risalah Fiqhiyyah, Risalah Tajwidil Qur'an (Targhibul Ikhwan Fi Tajwidil Qur'an, Durusut Tashrif (4 jilid), Sirah Sayyidil (Sejarah Nabi Muhammad Saw). Ia wafat pada malam Senin, 18 Syawal 1359 Hijriah.

Suatu hal yang sangat penting dalam sejarah sosial ekonomi berkaitan dengan peluang usaha. Dalam setiap zaman, senantiasa muncul primadona usaha yang menjadikan seseorang menjadi saudagar. Misalnya, dalam abad ke17 dan 18, kemunculan saudagar Banjar dari kelompok bangsawan Banjar

\footnotetext{
23 Tim Sahabat, 100 Tokoh Kalimantan (Kandangan: Penerbit Sahabat, 2007), hlm. 111-112

24 Ibid. hlm. 113-114.

25 Ibid. hlm. 115-116.

26 Ibid. hlm. 116, 117, 118.
} 
disebabkan permintaan komoditas lada bagi perdagangan dunia yang sangat meningkat tajam. Goh Yoon Fong menyebutkan, Banjarmasin sebagai salah satu penghasil utama lada terbesar di Asia Tenggara selama periode 17001747.27 Dalam periode ini, Sultan Banjar yang menikmati keberuntungan dari produksi lada adalah Sultan Amirullah Bagus Kesuma (1680-1708), Sultan Suria Alam (1708-1718), Sultan Kesuma Dilaga (1718-1730), Sultan Hamidullah (17301734). 28 Kemajuan dagang ditopang transportasi sungai yang baik. Letak sungai langsung terhubung dengan Laut Jawa. Muara Sungai Martapura dan Sungai Barito menjadi lalu lintas perdagangan yang sangat ramai.29 Dalam konteks perdagangan lada ini, tentu melibatkan unsur pribumi lainnya, termasuk para tokoh lokal setempat, yakni para saudagar dari bubuhan para Tuan Haji.

Martapura dalam tahun 1900 memiliki tingkat keamanan yang cukup, maka seiring dengan pertambahan penduduk diperlukan makanan pokok, dalam hal ini beras. Usaha membuka persawahan dan penggilingan padi merupakan usaha yang paling penting pada tahun 1900-an.30 Bahkan pada kawasan Sungai Martapura yang penuh rawa ada upaya untuk dikeringkan bagi kepentingan pertanian.31 Begitu pula usaha dalam penanaman karet dan dengan tingkat harga tinggi tanpa memperbesar produksinya di tahun 1920.32 Selain itu, usaha penyewaan transportasi sungai menjadi penting dalam kerangka mengangkut kebutuhan produksi. Juga usaha penambangan berlian serta jual belinya.33 Peluang usaha demikian, berdampak bagi peningkatan orang naik Haji dari Banjar dalam tahun 1925, dengan jumlah peningkatan mencapai $40 \% .34$

Tuan Haji sebagai saudagar Banjar di Martapura memiliki ikatan sosial religius dengan kelompok Ulama (Tuan Guru) Martapura. Fenomena demikian tidak bisa dilepaskan dari akar budaya Banjar di Martapura yang menempatkan Ulama (Tuan Guru) sebagai bagian penting dalam semua aspek kehidupan masyarakat.

Diantara saudagar kaya di Martapura Kalimantan Selatan sejak tahun 1920-an adalah Tuan Haji Setta. Tuan Haji Setta anak dari pasangan Haji

${ }^{27}$ Goh Yoon Fong. Perdagangan dan Politik Banjarmasin 1700-1747. (Yogyakarta: Lilin, 2013), hlm. i.

$28 \mathrm{Ibid}, \mathrm{hlm}$. ix.

${ }^{29}$ Paulus, J., Encyclopaedie van Nederlandsch Indië, eerste deel ('s Gravenhage, 1917, M. Nijhoff), hlm 97-98.

${ }^{30}$ Lihat Linblad, Op.cit, hlm.25-26

${ }^{31}$ ANRI, Natuur in Zuid-en Oost Borneo (Elfde Jaarverslag 1936-1938) Van de Nederland Indie Vereeniging tot Natuurbescherming, Batavia, hlm. 375.

32 Linblad, Op.cit, hlm. 59, 109.

33 Ibid. hlm. 182.

34 Ibid. hlm. 110. 
Muhammad Arsyad35 dengan Hajjah Tuan Pulan. Tuan Haji Setta memiliki isteri keturunan Tionghoa muslimah bernama Hajjah Intan, dari marga Lim.

Berbagai usaha dan perdagangan dikerjakan Tuan Haji Setta. Misalnya, Usaha bajak di tanah sewaan milik Haji Setta. Ada sebuah pabrik intan milik Haji Setta yang bekerjasama dengan orang Arab. Sementara Haji Setta juga memiliki sebuah pabrik es pribumi dan sebuah pabrik karet yang dikelola atas dasar kongsi. Untuk perahu yang ada terdiri atas 30 perahu pengangkut batubara, 37 perahu tambang dan 16.423 perahu jukung.36 Seiring dengan ramainya perahu di Sungai Martapura dan Muara Banjarmasin, Belanda menggiatkan pengawasan dengan menyiapkan patroli sungai dengan menggunakan perahu pula.37 Pabrik karet dimiliki oleh Haji Setta melalui kongsinya. Orang sibuk mencari investasi. Haji Setta telah memiliki akses yang luas dengan kalangan pejabat Belanda dan pengusaha Belanda.38

Tuan Haji Setta mampu membangun kerjasama dengan birokrat dan pengusaha Belanda yang non muslim. Bahkan, ketika ia sempat diundang ke Belanda, Tuan Haji Setta dan anaknya Tuan Haji Abdurrahman, tetap menggunakan pakaian Ulama Banjar. Ia tetap memakai surban, gamis dan jubah. Kemampuannya bernegosiasi sebagai pedagang dan pengusaha muslim yang jujur, menyebabkan usahanya sangat maju, dan mendapat kepercayaan penuh dari kalangan pengusaha Belanda.39

Tuan Haji Setta telah membuka pabrik es (1928) ketika tiba-tiba dia berpikir tentang kinerja mesin untuk penggilingan ubi kayu dan pengeringan mesin untuk ujung intan. Tanaman pertanian adalah padi, yang ditanam di berbagai tempat sesuai dengan kondisi tanah. Tuan Haji Setta memiliki sawah yang luas untuk ditanami padi. Hasil padi sawah miliknya, menyokong ketersediaan beras di Martapura khususnya, sekaligus membantu masyarakat kampung untuk mengerjakan sawah miliknya. Pengerjaan sawah dengan sistem aron, artinya hasil padi ketika panen separo untuk petani yang mengerjakan, separonya untuk pemilik lahan. 40

Pabrik karet milik Tuan Haji Setta dan kongsinya pada tahun 1927 menghasilkan 1931 pikul karet kering atau 120.687 kilogram.41 Hasil karet ini menunjukkan hasil yang besar, bagi kemajuan usaha Tuan Haji Setta dan

35 ANRI, Memorie Van Overgave Voor De Onderafdeeling Martapoera Door Controleur J. Wentholt, 10 Nov. 1938. Reel no. 30, MvO serie 1e, ANRI hlm. 28-29).

${ }^{36}$ ANRI, Memorie van Overgave Onderafdeeling Martapoera Door H.M. Holtrust Reel no. 30, MvO serie 1e, ANRI 1928, hlm. 20-21

${ }^{38}$ ANRI, Memorie Van Overgave H.N.A. Swart Reel nomor 3 MvO DL, ANRI tertanggal 16 Oktober 190, hlm. 14-15.

${ }^{38}$ ANRI, Memorie van Overgave Onderafdeeling Martapoera Door H.M. Holtrust, Op.cit . hlm. 22

${ }^{39}$ ANRI, Memorie van Overgave Onderafdeeling Martapoera Door H.M. Holtrust Reel no. 30, MvO serie 1e, ANRI 1928, hlm. 21

40 Ibid, hlm.22

41 Ibid. hlm. 22 
keluarganya. Sebagian masyarakat kampung ikut bekerja di pabrik karet tersebut.

Usaha penggosokan intan Haji Setta hanya memiliki 12 orang pekerja. Mereka mengerjakan penggosokan intan dengan sangat baik. Intan yang digosok dari hasil tambang milik Haji Setta sendiri. Wilayahnya, sekitar kampung Cempaka Martapura (sekarang masuk kawasan kota Banjarbaru).

Setiap habis sholat Jum'at, Tuan Haji Setta melakukan muzakarah Ilmu di rumahnya, kampung Pasayangan Martapura Kabupaten Banjar Kalimantan Selatan. Teman muzakarahnya adalah Tuan Guru Muhammad Kasyful Anwar. Selain itu, ada beberapa Tuan Guru lainnya. Selesai muzakarah ilmu, mereka bermusyawarah untuk memajukan pengajian di Darussalam. Pengajian Darussalam sebelumnya berbentuk pengajian Sorogan tanpa ada jenjang kelas. Para murid diajarkan kitab-kitab fiqih, ilmu Hadist dan Alqur'an, dan lain-lain. Sejak tahun 1922, Tuan Guru Muhammad Kasyful Anwar ditunjuk sebagai pimpinan Pondok Pesantren Darussalam menggantikan Tuan Guru Haji Hasan Ahmad.42

Madrasah Darussalam sebelumnya bernama al-Imad fi Ta'lim al-Aulad. Resmi berdiri tanggal 14 Juli 1914, yang dipelopori Tuan Guru Haji Jamaluddin (1914-1919) kemudian diteruskan Tuan Guru Haji Hasan Ahmad (1919-1922). Pengajaran dengan cara Sorogan diganti dengan cara klassikal oleh Tuan Guru Haji Muhammad Kasyful Anwar, dan nama madrasah sebelumnya diganti dengan Madrasah Darussalam, tahun 1922. 43

Pemerintah Kolonial mengawasi ketat Pendidikan Islam,44 namun Tuan Guru Muhammad Kasyful Anwar dan Tuan Haji Setta bersepakat membangun Madrasah Darussalam dengan cara membangun kelas-kelas. Pembelajaran menggunakan meja dan kursi, sebagaimana pembelajaran yang dilaksanakan Arabische School di Banjarmasin. Pada mulanya, sebagian Tuan Guru menentang sistem kelas ini. Namun, dengan kegigihan Tuan Guru Haji Muhammad Kasyful Anwar, para Tuan Guru yang lain sebagian besar menyetujui.

Biaya pembangunan madrasah Darussalam, yang kemudian bernama Pondok Pesantren Darussalam Martapura Kabupaten Banjar Kalimantan Selatan itu, dapat berdiri atas infaq Tuan Haji Setta. Letaknya di Pinggir Sungai Martapura, kampung Pasayangan. Pada mulanya jumlah kelas terdiri dari enam kelas. Satu kelas terdiri dari 30 sampai 40 murid. Jumlah biaya yang dikeluarkan Tuan Haji Setta untuk pembangunan pesantren itu tidak

42 Rahmadi Jaringan Intelektual Ulama Banjar Abad XIX dan XX (Studi Tentang Proses, Pola dan Ekspansi Jaringan). (Banjarmasin, Antasari Press, 2010), hlm. 191.

43 Syaharuddin, Orang Banjar Menjadi Indonesia Dinamika Organisasi Islam di Borneo Selatan 19121942, (Yogyakarta: Eja Publisher, 2011), hlm. 130-131.

44 ANRI, Memorie van overgave Betreffende De Onderafdeeling Martapoera kontroler A.M. van Hekking Reel no. 30, Mv O Serie, Le, ANRI, hlm. 25. 
disebutkan. Holtrust melaporkan pendirian pesantren Darussalam sebagai berikut:

“Di ibukota Martapura sebuah sekolah agama didirikan di atas petak hak milik dengan 385 orang murid dan 7 tenaga pengajar. Gedungnya disebut Darussalam dan berasal dari cabang SI lokal. Bantuan keuangan terutama berasal dari Haji Setta. Tiga guru terkenal setiap bulan menerima f 40 dan f 20." 45

Saat pembangunan Pondok Pesantren Darussalam Martapura Kabupaten Banjar Kalimantan Selatan itu, masyarakat sekitar kota Martapura ikut bergotong royong (gawi sabumi), dibantu sebagian besar murid-murid pengajian Sorogan. Pembelajaran sistem Sorogan terus diterapkan, sebelum bangunan pesantren rampung.

Tuan Haji Setta selain mendukung biaya pembangunan gedung dan tanah, juga biaya penyediaan kursi dan meja serta kelengkapan pembelajaran di dalam kelas. Di lain pihak, Tuan Guru Haji Muhammad Kasyful Anwar selalu mendo'akan bersama murid-murid Pesantren Darussalam untuk kelancaran usaha Tuan Haji Setta. Pekerja Tuan Haji Setta yang mengerjakan sawah, menyadap karet, membuat lateks (getah asap), penggosok intan, para pengayuh jukung, dan lain-lainnya, selalu jujur dan setia kepada Tuan Haji Setta. Mereka adalah kaum muslimin dan muslimat yang meyakini kedermawanan Haji Setta untuk kepentingan kemajuan pendidikan Islam di Martapura Kabupaten Banjar Kalimantan Selatan.

Keberadaan Madrasah Darussalam mandapat sambutan luas sehingga menjadi pendidikan Islam yang paling diminati masyarakat Martapura dan juga dari masyarakat Borneo Selatan lainnya.46 Sampai sekarang Madrasah Darussalam terus berkembang dan menjadi pondok Pesantren yang punya santri terbesar di Kalimantan Selatan.47 Pesantren Darussalam menerapkan dua kurikulum sekaligus yakni pendidikan pondok salafi (khusus pendidikan agama dengan cirinya mengkaji kitab-kitab kuning) dan pendidikan modern dengan mengikuti pola kurikulum pendidikan Departemen Agama yaitu Madrasah Tsanawiyyah dan Madrasah Aliyyah.48

Setelah menamatkan pendidikan di Pesantren Darussalam Martapura, sebagian besar murid-muridnya kembali ke kampung masing-masing. Kemudian mereka mendirikan madarasah-madrasah swasta yang dikelola masyarakat kampung. Para alumnus ini mampu menjadi guru-guru agama

45 ANRI, Memorie van Overgave Onderafdeeling Martapoera Door H.M. Holtrust Reel no. 30, MvO serie 1e, ANRI 1928, hlm.16. F 1, jika dikonversi ke rupiah saat ini, tahun 2018, sama dengan harga 10 kilogram gula. Jika harga gula $1 \mathrm{~kg}$ sebesar Rp. 11.000,00 maka f 40x 77.000,00=Rp. 3.380.000,-

46 Humaidy, "Pondok Darussalam Dalam Lintasan Sejarah", Kandil Edisi 2, Tahun 1

(September 2003), hlm. 64. Lihat pula Syaharuddin, Op.cit.,hlm. 131.

47 Syaharuddin, Ibid.,

48 Ibid. 
Islam di kampungnya. Mereka mampu membaca kitab kuning, menjadi Khatib, Penghulu, dan menjadi Tuan Guru di kampungnya. Alumnus-alumnus madrasah Ibtidaiyah dari berbagai kampung di Martapura Kabupaten Banjar Kalimantan Selatan kemudian meneruskan jenjang tingkat Tsanawiyah atau sampai Aliyah (Ulya) di Pesantren Darussalam Martapura Kabupaten Banjar Kalimantan Selatan.

\section{KESIMPULAN}

Sebutan Kota Santri dan Serambi Mekkah bagi Kota Martapura Kabupaten Banjar Kalimantan Selatan tidak bisa dilepaskan dari eksistensi Pondok Pesantren Darussalam. Pesantren yang semula hanya bersifat Sorogan dengan murid tercatat dalam tahun 1922 sebanyak 385 orang. Pondok Pesantren Darussalam Martapura Kabupaten Banjar Kalimantan Selatan dalam tahun 1922 dibangun dengan sistem kelas. Rampung dalam tahun 1924. Atas inisiatif Tuan Guru Muhammad Haji Kasyful Anwar dengan dukungan dana infaq dari Tuan Haji Setta, seorang pedagang dan pengusaha dari kampung Pasayangan Martapura Kabupaten Banjar Kalimantan Selatan. Tuan Haji Setta selain saudagar juga seorang Ulama yang senang bermuzakarah dalam masalah Islam dan Keummatan. Pendirian Pesantren ini didukung sepenuhnya oleh Nahdlatul Ulama (NU) dan Sarekat Islam (SI) Martapura. Tuan Haji Setta mampu membuktikan bekerjasama dalam bentuk investasi dari pengusaha Belanda yang non muslim tidak menjadi penghambat bagi dirinya untuk memajukan dan menguatkan pendidikan Islam di Martapura Kalimantan Selatan.

Kerjasama Tuan Guru (Ulama) dengan Tuan Haji (saudagar) dalam mendirikan Pondok Pesantren Darussalam Martapura Kabupaten Banjar Kalimantan Selatan, menjadi bagian penting untuk memahami eksistensi terpeliharanya aqidah ummat Islam di daerah tersebut. Meskipun sebagian masyarakat muslim Martapura sekolah pagi, yakni sekolah umum milik Pemerintah Kolonial Belanda, namun sore harinya mereka sekolah madrasah di kampung-kampung dan nyantri di rumah-rumah para Tuan Guru pada malam harinya. Realitas ini, merupakan berkah dari hadirnya Pondok Pesantren Darussalam Martapura Kabupaten Banjar Kalimantan Selatan, yang menghasilkan ribuan alumnus setingkat Aliyah (Ulya). Kuatnya pengaruh peradaban Islam dari pendidikan Islam bagi orang Banjar di Martapura dibuktikan dengan adanya perasaan sangat malu jika tidak pandai membaca Alqur'an, dan menulis tulisan dengan menggunakan huruf Arab.

\section{DAFTAR PUSTAKA}

A. K. Pringgodigdo. Sejarah Pergerakan Rakyat Indonesia, Jakarta: PT. Dian Rakyat, 1978. Abdurrahman, "Menelusuri Karya Tulis Ulama Banjar (Bagian IV) Menelusuri Karya Syekh Muhammad Arsyad Al-Banjari", Surat Kabar Dinamika Berita, 21 November 1991. 
JUSPI: Jurnal Sejarah Peradaban Islam

Abu Daudi, Maulana Syekh Muhammad Arsyad Al-Banjari (Tuan Haji Besar). Martapura-Kalsel: Yayasan Pendidikan Islam Dalam Pagar, 2003.

Alex A. Koroh, Lintasan Sejarah Pemerintahan Daerah di Kalimantan Selatan 1901-1957. Banjarbaru: Scripta Cendekia, 2009.

ANRI, Memorie Van Overgave H.N.A. Swart Reel nomor 3 MvO DL, ANRI tertanggal 16 Oktober 190,

ANRI, Memorie van overgave Betreffende De Onderafdeeling Martapoera kontroler A.M. van Hekking Reel no. 30 , Mv O Serie, Le, ANRI.

ANRI, Memorie van Overgave Onderafdeeling Martapoera Door H.M. Holtrust Reel no. 30, MvO serie 1e, ANRI 1928.

ANRI, Memorie Van Overgave Voor De Onderafdeeling Martapoera Door Controleur J. Wentholt, 10 Nov. 1938. Reel no. 30, MvO serie 1e, ANRI.

ANRI, Memorie Van Overgave Voor De Onderafdeeling Martapoera Door Controleur J. Wentholt, 10 Nov. 1938. Reel no. 30, MvO serie 1e, ANRI

ANRI, Natuur in Zuid-en Oost Borneo (Elfde Jaarverslag 1936-1938) Van de Nederland Indie Vereeniging tot Natuurbescherming, Batavia.

Goh Yoon Fong. Perdagangan dan Politik Banjarmasin 1700-1747. Yogyakarta: Lilin, 2013.

H.M. Holtrust. Memorie van Overgave Onderafdeeling Martapoera Door Reel no. 30, MvO serie 1 e. ANRI, 1928.

Helius Sjamsuddin, Pagustian dan Tumenggung, Akar Sosial, Politik, Etnis, dan Dinasti Perlawanan di Kalimantan Selatan dan Kalimantan Tengah 1859-1906. Jakarta: Balai Pustaka, 2001.

Ita Syamtasiah Ahyat. Kesultanan Banjarmasin Pada Abad Ke-19 Ekspansi Pemerintah Hindia-Belanda di Kalimantan. Tangerang: SAM, 2012.

J. Thomas Linblad. Antara Dayak dan Belanda, Sejarah Ekonomi Kalimantan Timur dan Kalimantan Selatan 1880-1942. Malang-Jakarta: Lilin-KITLV, 2012.

J.F.A. de Rooy, Memorie Van Overgave, Reel nomor 3, MvO DL, ANRI, 1905.

M. Idwar Saleh, dkk. Sejarah Daerah Kalimantan Selatan. Banjarmasin: Proyek Penelitian Pencatatan Daerah Depdikbud, 1978.

M. Ramli Nawawi et.al, Sejarah Pendidikan di Kalimantan Selatan. Banjarmasin: Departemen Pendidikan dan Kebudayaan Kalimantan Selatan. 1981.

Paulus, J., Encyclopaedie van Nederlandsch Indië, eerste deel's. Gravenhage, 1917.

Rahmadi Jaringan Intelektual Ulama Banjar Abad XIX dan XX (Studi Tentang Proses, Pola dan Ekspansi Jaringan). Banjarmasin: Antasari Press, 2010.

Sjarifuddin. Sikap Pergerakan Rakyat Menghadapi Pendudukan Belanda di Kalimantan Selatan Periode 1945 sampai Dengan 17 Agustus 1950, Banjarmasin: Fakultas Keguruan Universitas Lambung Mangkurat, 2001.

Syaharuddin, Orang Banjar Menjadi Indonesia Dinamika Organisasi Islam di Borneo Selatan 1912-1942. Yogyakarta: Eja Publisher, 2011.

Tamny Ruslan. Gerakan Muning: Sebuah Gerakan Sosial di Dalam Perang Banjar. Tesis. Yogyakarta: Fakultas Sastra dan Kebudayaan Universitas Gadjah Mada dalam Ilmu Sejarah, 1981.

Tim Sahabat. 100 Tokoh Kalimantan. Kandangan: Penerbit Sahabat, 2007.

Yusliani Noor. Islamisasi Banjarmasin (Abad Ke-15 Sampai Ke-19). Yogyakarta: Penerbit Ombak, 2016.

Yustan Aziddin et.al, Cerita Rakyat Daerah Kalimantan Selatan. Jakarta: departemen Pendidikan dan Kebudayaan Proyek Inventarisasi dan Dokumentasi Kebudayaan Daerah, 1981). 